\title{
INFLUENCE OF BODY CONDITION SCORE ON BLOOD METABOLITES AND OXIDATIVE STRESS IN PRE- AND POST-CALVING OF FRIESIAN DAIRY COWS IN EGYPT
}

\author{
Mohamed E. El-Sharawy ${ }^{1}$, Ibrahim M. Mashaly², Mustafa S. Atta ${ }^{3}$, Mostafa Kotb², \\ Ibrahim S. El-Shamaa ${ }^{1 *}$
}

\begin{abstract}
${ }^{1}$ Animal Production Department, Faculty of Agriculture, Kafrelsheikh University, 33516, Egypt, ${ }^{2}$ Animal Production Research Institute, Agriculture Research Center, El-Dokki, Giza, Egypt, ${ }^{3}$ Department of Physiology, Faculty of Veterinary Medicine, Kafrelsheikh University, Egypt
\end{abstract}

${ }^{*}$ Corresponding author, E-mail: elshamaa2008@yahoo.com

\begin{abstract}
This experiment aimed to study the relation of body condition score (BCS) with blood metabolites in dairy cow. At 8 weeks before expected parturition, 90 multiparous Friesian dairy cows were divided according to their body condition score into 3 groups: Group1: low body condition score $(n=30, B C S \leq 2.58$, thinner cows); Group2: medium body condition score ( $n=30, B C S \leq 3.12$, medium BCS cows); Group3: high body condition score $(n=30, B C S \leq 4.75$, obesity cows). The cows BCS, weight and back fat thickness were recorded at $-60,-21,-14,-7,0,7,14$ and 60 days related to calving time. Blood samples were taken at the time of BCS measurement for determination of $\beta$ hydroxy butyrate, non-esterified fatty acid, haptoglobin, glucose, triglyceride, albumin, aspartate aminotransferase, cholesterol, superoxide dismutase and malonaldehyde. The results showed a significant decrease in body condition score, body weight and back fat thickness throughout the experimental period accompanied by an increase in $\beta$ hydroxy butyrate, malonaldehyde and cholesterol. The correlation analysis showed that changed body condition score positively allied with cow weight $(r=0.860, P<0.01)$, back fat thickness $(r=0.977 P<0.01)$, malonaldehyde $(r=0.445, P<0.01)$ and cholesterol $(r=0.342$, $P<0.01)$ and was negatively correlated with $\beta$ hydroxy butyrate $(r=0.416, P<0.01)$, haptoglobin $(r=-0.232, P<0.05)$, non-esterified fatty acid $(r=-0.457, P<0.01)$, albumin $(r=-0.133$, $P>0.05)$ and aspartate aminotransferase $(r=-0.361, P<0.01)$. Concisely, body condition score loss before and after calving may have significant consequences for blood metabolites, oxidative stress and body condition score profile in dairy cows.
\end{abstract}

Key words: BCS; calving; blood metabolites; Friesian cow

\section{Introduction}

The transition period extends from 21 days ante partum to 21 days postpartum and can be described as the alteration from a gestational non-lactating state to a non-gestational lactating stage $(1,2,3)$. The body condition score is a reliable, simple way of estimating the nutritional status, body reserves and energy balance in dairy cows. Its evaluation is centered on the outer appearance of cows that interrelates with its body fat reserves and so, influenced by the 
energy balance (4). Lowman and Somerville (5) were the first to use a BCS Scale (4- points), even so, the scale used to measure the BCS (5-, 6-, 8-, and 10- point scales) differs between the countries. But, collectively, the low values always reflect the emaciation while the high value equate to obesity (6). Back fat thickness (BFT) related to other approaches of body condition scoring because its objective and precise. Nearby parturition, the adipose tissue begins to decompose to create fatty acids and glycerol (lipolysis) afford energy to the body. Non-esterified fatty acid (NEFA) in blood is a respectable pointer of adipose tissue mobilization (7). NEFA and $\beta$ hydroxy butyrate (BHBA) are important energy metabolites that are traditionally used as indicator of negative energy balance (NEB) during transition stage (8). The determination of malonaldehyde (MDA) and activity of superoxide dismutase (SOD) during transition period as an index of oxidative stress status.

The aim of the present study was to explore the relationship between body condition score from 60 days' pre- partum until 60 days' postpartum and BCS change, BW, BFT and some metabolic blood parameters in pregnant Friesian dairy cows.

\section{Materials and methods}

The experimental protocol was approved by the Animal Care and Use Committee of Faculty of Agriculture, Kafrelsheikh University.

\section{Animals}

A total of 90 animals formed a herd of 350 Friesian dairy cows selected for experiment depend on their body weight (BW) and body condition score (BCS) 0 to 5 point scale according to the North American BCS (9), and divided into three groups (each of 30 cows) on $60^{\text {th }}$ days pre-partum as fairly low (group 1, $\leq 2.58$ $\mathrm{BCS}, \leq 490 \mathrm{~kg} \mathrm{BW}$ ), medium (group $2, \leq 3.12$ $\mathrm{BCS}, 600 \mathrm{~kg}$ ) and obesity (group $3, \leq 4.75 \mathrm{BCS}$, $\leq 713 \mathrm{~kg} \mathrm{BW}$ ). The body condition score was performed by one person at $-60,-21,-14,-7$ prepartum, at day of calving, at days 7, 14 and 60 post-partum. Animals were housed in a free stall barns, had a free access to water and fed twice daily ( 8 am and $4 \mathrm{pm}$ ) with a ration formulated according to the recommendation of NRC (10) (Tables 1 and 2).

\section{Measurement of back fat thickness (BFT)}

The investigation site is positioned in the sacral region among the caudal quarter and fifth connection line extending from the dorsal portion of the tuber ischia (pins) to the tuber coxae and is evaluated by ultrasound (4) and the data was converted to BCS.

\section{Biochemical assessment}

Blood samples were taken from the jugular vein of all cows on fixed time before morning feeding at $-60,-21,-14,-7$, pre- partum, at day of calving and at days 7, 14 and 60 post-partum. Serum were stored at $-20{ }^{\circ} \mathrm{C}$ till essayed for NEFA, BHBA, haptoglobin (HP), and other biochemical analysis. NEFA and BHBA quantified using commercially kits (Randox laboratories Ltd, Crumlin Co., Antrim, UK), Serum Hp measured calorimetrically using a commercial kit (Phase HP kit, Tridelta Ltd., Ireland) according to the constructor's guidelines.

MDA and SOD assessed using the commercially kit (Bio-diagnostic, Egypt) according to (11). Albumin, triglycerides, glucose, cholesterol and aspartate aminotransferase assessed spectrophotometrically using autoanalyzer (MCC-3000, China) (Biomed diagnostics Germany).

\section{Statistical analysis}

Mean and standard error were calculated. The obtained data were subjected to two-way factorial analysis of variance according to the procedures out lined by Snedecor and Cochran (12). The mean value of treatments was compared according to Duncan's multiple range test (DMRT) (13). Multiple correlation coefficient analyses were used. The data was analyzed using CoStat software for windows (version 6.3).

\section{Results}

Change of BCS, BW and BFT from pre-to post- partum in dairy cows

Fluctuations of BCS in each group were presented in figure 1. The obesity BCS cows 
showed significantly higher BCS reduction (1.17) $60 \mathrm{~d}$ pre-partum to $60 \mathrm{~d}$ post-partum than thinner (-0.5) and medium BCS cows (-0.67). Changes of BW and BFT were statistically significant $(\mathrm{P}<0.05)$ among the 3 groups (Fig. 2 and 3 ). The $3^{\text {rd }}$ group showed higher BW and BFT reduction from d 60 before calving to $\mathrm{d} 60$ after calving (106 kg and 1.14 , respectively) compared to thinner $(70 \mathrm{~kg}$ and 0.28 , respectively) and medium groups (103 kg and 0.68 , respectively). During the experimental time, highly significant positive correlations were found among reduction of BCS and both of BW $(\mathrm{r}=0.86, \mathrm{P}<0.01)$ and BFT $(\mathrm{r}=0.98, \mathrm{P}<0.01)$. Thus, cows with greater BCS losses had also higher BW and BFT losses (Table 3).

\section{Metabolic parameters}

Serum concentrations of BHBA, NEFA and $\mathrm{HP}$ in high BCS cows were significantly $(\mathrm{P}<0.05)$ higher than the other two groups before and after calving (Figs, 4-6). The differences in HP among groups were not significant. The concentrations of BHBA and NEFA increased from $-7 \mathrm{~d}$ before calving and reached the high levels on $7 d$ post- calving and then decreased with high values as compared to those observed before parturition.

\section{Oxidant and antioxidant status}

SOD gradually increased $(\mathrm{P}<0.05)$ in the last 21 days of pregnancy (at $21 \mathrm{~d}$ before calving) and reached the maximum at $7 \mathrm{~d}$ earlier calving. After parturition, SOD dropped to reach the levels recorded before calving (Fig. 7). Serum concentration of MDA was relatively steady before calving $(\mathrm{P}>0.05)$ at parturition and one week after calving (Fig. 8). The differences among groups were highly significant $(\mathrm{P}<0.01)$.

\section{Serum biochemical parameters}

The concentrations of serum glucose were gradually increased from $-60 \mathrm{~d}$ before calving and reached the highest values at calving and then dropped sharply at $7 \mathrm{~d}$ post-calving and back increased to the levels registered $60 \mathrm{~d}$ before calving (Fig. 9). Serum triglyceride was not significantly differed among groups (Fig. $10)$. The serum cholesterol started to increase from $-60 \mathrm{~d}$ before calving and reached the higher values on $-7 \mathrm{~d}$ before calving and then decreased to reach the low values on $60 \mathrm{~d}$ postcalving (Fig. 11), while the triglyceride concentration peaked at calving and dropped $7 \mathrm{~d}$ and 14 $\mathrm{d}$ post-calving and then increased $60 \mathrm{~d}$ postcalving. Mean serum albumin content dropped to the lowest levels at calving followed by a subsequent increase to highest levels $(\mathrm{P}<0.05)$ at $7 \mathrm{~d}$ post-calving then dropped to levels $60 \mathrm{~d}$ pre-calving and followed by an increase at $60 \mathrm{~d}$ post-calving. The differences among groups did not significantly differed (Fig. 12). AST concentrations steady increased $(\mathrm{P}<0.05)$ from 60 $\mathrm{d}$ before calving to parturition and followed by a subsequent increase at one wk., 2 wk and 2 months post-calving and reached maximum level $(\mathrm{P}<0.05)$ at $60 \mathrm{~d}$ post- calving (Fig. 13).

\section{Correlation study}

BCS, BW and BFT were negatively $(\mathrm{P}<0.01)$ correlated with both BHBA $(\mathrm{r}=-0.416$, $\mathrm{r}=-0.355, \mathrm{r}=-0.361$, respectively), NEFA ( $\mathrm{r}=-$ $0.457, \mathrm{r}=-0.470$ and $\mathrm{r}=-0.448$, respectively), and AST $(r=-0.361, r=-0.407$ and $r=-0.341$, respectively) and were definitely $(\mathrm{P}<0.01)$ linked with cholesterol $(\mathrm{r}=0.342, \mathrm{r}=0.423$ and $\mathrm{r}=0.323$, respectively), (Table 3 ). 
Table 1: Chemical composition of ingredients rations during the pre- and the post- partum period

\begin{tabular}{|l|l|l|l|l|l|l|l|}
\hline Item & \multicolumn{6}{|c|}{ Composition of DM\% } \\
\hline Ingredients & DM\% & OM & CP & CF & EE & NFE & Ash \\
\hline CFM & 89.71 & 91.58 & 15.62 & 9.63 & 2.92 & 63.41 & 8.42 \\
\hline Corn silage & 35.10 & 94.89 & 9.39 & 23.18 & 2.19 & 60.13 & 5.11 \\
\hline Hay & 89.89 & 92.23 & 14.29 & 27.5 & 3.12 & 47.32 & 7.77 \\
\hline Rice straw & 91.08 & 83.58 & 2.98 & 34.89 & 1.36 & 44.39 & 16.42 \\
\hline Rations & \multicolumn{7}{|l|}{} \\
\hline Pre-partum & 78.97 & 91.58 & 12.84 & 18.44 & 2.66 & 57.64 & 8.42 \\
\hline Close up & 76.24 & 91.74 & 12.54 & 19.12 & 2.62 & 57.46 & 8.26 \\
\hline Post- partum & 73.5 & 91.91 & 12.23 & 19.79 & 2.59 & 57.30 & 8.09 \\
\hline
\end{tabular}

DM (dry matter); OM (organic matter); CP (crude protein); CF (crude fiber); EE (ether extract); NFE ( Nitrogen free extract); Ash (Ash) and CFM (concentrate feed mixture)

Table 2: Average daily feed intake ( $\mathrm{Kg} /$ head/day) during pre- and post-partum period

\begin{tabular}{|l|l|l|l|}
\hline Item & Pre- Partum & Close up & Post- Partum \\
\hline $\begin{array}{l}\text { CFM (concentrate feed } \\
\text { mixture) }\end{array}$ & 9.5 & 8.5 & 7.6 \\
\hline Corn silage & 9.7 & 12.1 & 14.5 \\
\hline Hay & 3.8 & 3.8 & 3.8 \\
\hline Rice straw & 1.9 & 1.9 & 1.9 \\
\hline
\end{tabular}

Table 3: Correlation coefficient between body condition score, body weight and back fat thickness with metabolic blood parameters and oxidative stress

\begin{tabular}{|l|l|l|l|}
\hline \multicolumn{1}{|c|}{ Items } & BCS & BW & BFT \\
\hline Body Condition Score & 1 & & \\
\hline Body Weight & $0.860(* *)$ & 1 & \\
\hline Back Fat Thickness & $0.977(* *)$ & $0.884(* *)$ & 1 \\
\hline$\beta$ hydroxy butyrate & $-0.416(* *)$ & $-0.355(* *)$ & $-0.361(* *)$ \\
\hline Non-esterified fatty acid & $-0.457(* *)$ & $-0.470(* *)$ & $-0.448(* *)$ \\
\hline Haptoglobin & $-0.232(*)$ & $-0.215(*)$ & -0.184 \\
\hline Superoxide dismutase & 0.123 & -0.019 & 0.054 \\
\hline Malonaldehyde & $0.445(* *)$ & $0.383(* *)$ & $0.465(* *)$ \\
\hline Blood Serum Glucose & 0.133 & 0.208 & 0.146 \\
\hline Blood Serum Triglyceride & 0.040 & 0.017 & -0.009 \\
\hline Blood Serum Albumin & -0.133 & -0.145 & -0.137 \\
\hline Aspartate aminotransferase & $-0.361(* *)$ & $-0.407(* *)$ & $-0.341(* *)$ \\
\hline Blood Serum Cholesterol & $0.342(* *)$ & $0.423(* *)$ & $0.323(* *)$ \\
\hline
\end{tabular}

BCS (body condition score), BW (body weight), BFT (back fat thickness)

$* *$ Correlation is significant at the 0.01 level (1-tailed)

* Correlation is significant at the 0.05 level (1-tailed) 

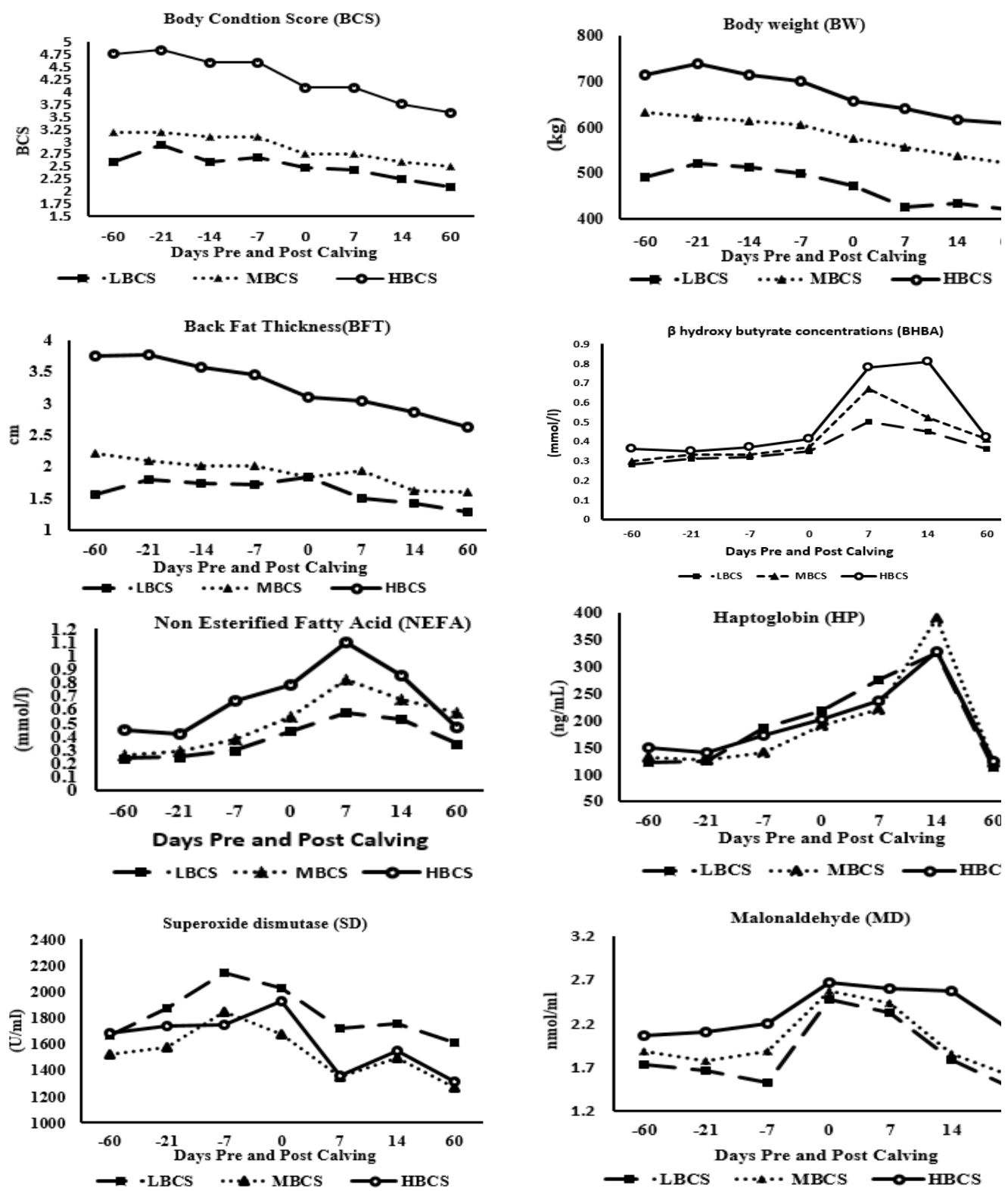

Figures 1-8: Effect of body condition score during pre- and post- calving on body condition score changes (BCS); body weight changes (BW); back fat thickness changes (BFT); $\beta$ hydroxy butyrate concentrations (BHBA); non-esterified fatty acid (NEFA); haptoglobin (HP); superoxide dismutase concentrations (SOD) and malonaldehyde concentrations (MD), (Means \pm SEM) 

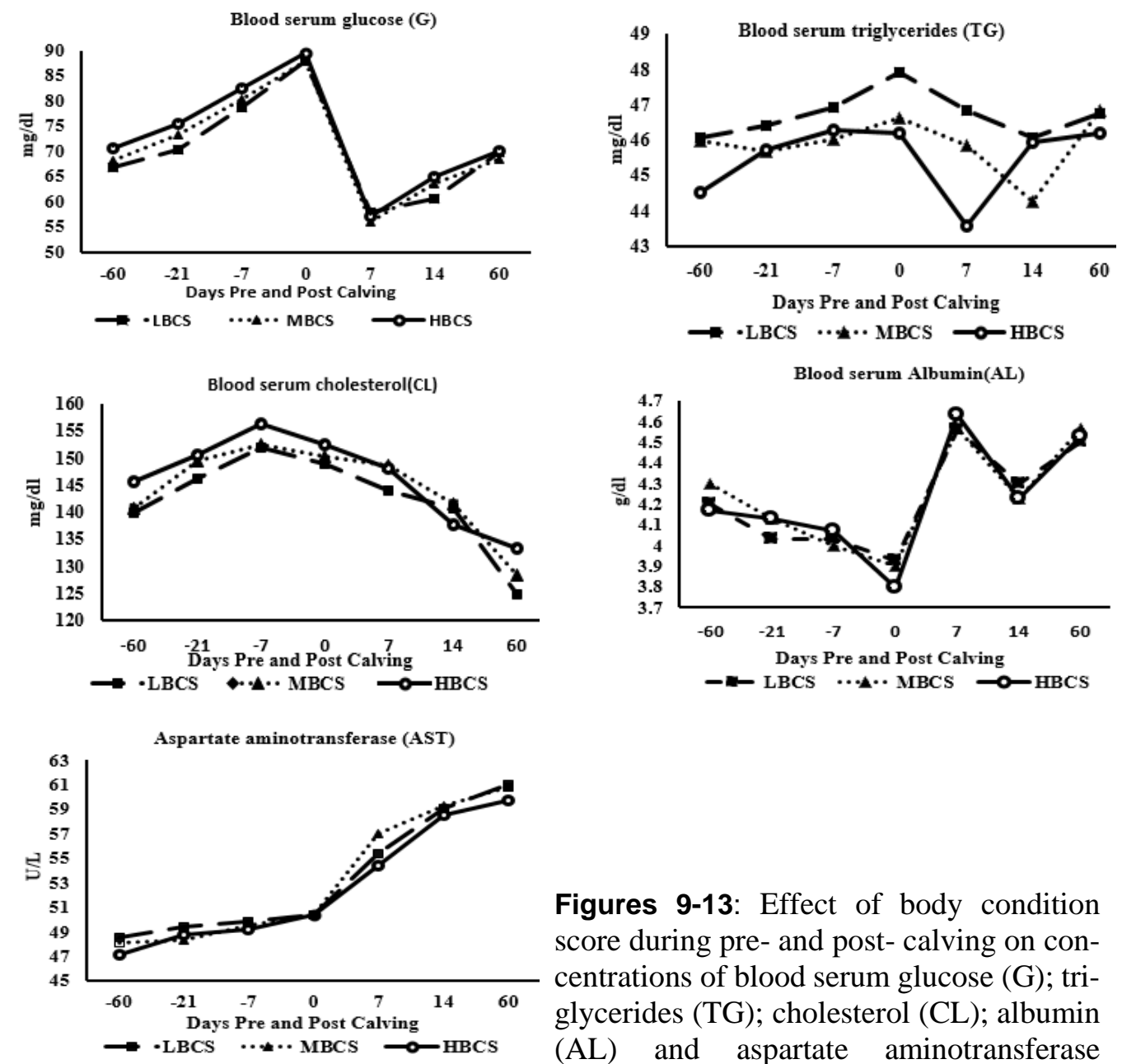

Figures 9-13: Effect of body condition score during pre- and post- calving on concentrations of blood serum glucose $(\mathrm{G})$; triglycerides (TG); cholesterol (CL); albumin (AL) and aspartate aminotransferase (AST), (Means \pm SEM)

\section{Discussion}

Cows with high body condition score showed higher $(\mathrm{P}<0.05)$ BCS loss pre and postcalving period than medium and thinner BCS cows. Greater loss of BCS in high BCS cows was expected and has been reported previously by Treacher et al. (14), who concluded that transition cows with great BCS waste more body weight and body condition than thinner one. In the present study, cows with high BCS had the greatest decline in BW and BFT when compared with the other groups, which is an indication of mobilizing greater body fat reserves than medium and thinner BCS cows. These results are in agreement with previous reports $(6,15$, 16).

In the present study, cows with high BCS had a sharp increase in plasma NEFA and
BHBA concentration, which reached the highest values at 1 week after calving, while the lowest levels were found in LBCS cows. The highest plasma NEFA and BHBA concentrations for cows with high BCS were in accordance with other studies (17) and could be explained by the high fat mobilization.

Results of the present study indicated that serum glucose increased in all groups reaching the peak at parturition then a sharp decrease $7 \mathrm{~d}$ post-calving, which may be attributed to cortisol and estrogen (17) or inherent hypoinsulinemia which reduce glucose uptake by tissue sensitive to insulin (18). On the other hand, García et al. (19) found that low glucose level was during calving and explained these results due to sever NEB suffered by the animals in this group that delivered high milk during the experimental time. Moreover, others found that glu- 
cose concentration remained stable and increase slightly at calving reflecting an increase in gluconeogenesis in response to calving stress $(20,21)$. Cheng et al. (22) reported that cows in negative EB have low rates of glucose and high levels of BHBA.

In the present study, triglycerides were relatively stable at range from 43.6 to $46.9 \mathrm{mg} / \mathrm{dl}$ and no significant differences were noticed among groups. This finding is consistent with previous report by García et al. (19) and González et al. (23) who attributed this to the excess of fatty acids mobilized to liver to be as energy resource. The reasons for such case are triglycerides accumulation in the liver and triglycerides taking up by the mammary gland for milk fat synthesis and secretion (24). Reduced cholesterol concentrations starting from the time at calving and post-calving weeks were found in all groups, which could be associated with reduced DM intake $(25,26)$. Conversely, Mouffok et al. (20) found that cholesterol was significantly elevated in post-partum which indicates good energy nutrition (27). Total cholesterol was significantly lower on week around parturition with the lowest value one week prior to calving $(28,29)$. Alternatively, García et al. (19) described that cholesterol level had a gradual upsurge as the lactation advanced.

Reduced albumin concentration reaching the lowest values at the time of parturition in all groups and increase to the highest values oneweek post calving. Our results are in disagreement with findings of Soca et al. (26), who found that albumin concentrations decreased after calving in low and moderate BCS cows and this may be associated with increasing of NEFA. Our results were in agreement with finding of Gheise et al. (16), who noted that the highest albumin levels at $1 \mathrm{~d}$ after calving. Albumin is synthesized via the liver and it's the core source of plasma thiol groups which are considered as an element of extracellular antioxidant defense against oxidative stress (30).

In the present study, the activity of aspartate amino transferase (AST) was not significantly changed by BCS on the calving day in all experimental groups and increased gradually at 7 ,
14 and $60 \mathrm{~d}$ post-calving. No significant different was found among groups pre and post-calving. The higher level of AST in dairy cattle are allied with the fatty liver syndrome, lower dry matter consumption and ketosis marks (32).

Haptoglobin (HP) concentration in the present study was significantly higher at calving day and post-calving days than before parturition. The present finding was in agreement with the finding of others $(31,32)$, who found that the highest value of HP was recorded in cows 3 wk postpartum. This finding supported the previous results of Montagner et el. (33) who found the trend for higher HP concentrations in cows' pre-partum and the enhanced concentration in the post-partum were consistent with impaired hepatic function.

Highest MDA concentration was recorded on the day of calving in all treated groups, then continuously decreased after calving on 7, 14 and $60 \mathrm{~d}$ post-calving that was in agreement with the finding of others (34). Castillo et al. (35) reported that MDA is the last product of lipid peroxidation, therefore changes of MDA concentrations can be used as a biomarker of oxidative stress. SOD enzyme is the major antioxidant defense competent in protecting the cells against increased ROS (36). The increase of SOD around calving ( $-7 \mathrm{~d}$ to $+7 \mathrm{~d}$ pre and post- calving) because of a possible homeostatic control (37).

\section{Conclusion}

This study showed that lost body condition in 8 wks before calving had an adverse metabolic status, with increased serum concentrations of NEFA, BHBA, MDA and AST post calving. In addition, high BCS cows (obesity, G3) had highest BHBA profiles that suggested they had a higher risk of subclinical ketosis, in addition, highest serum concentrations of NEFA in all cows after calving, indicated the highest mobilization of body reserves after calving.

\section{Conflict of interest}

The authors state no conflicts of interest. 


\section{Acknowledgements}

Honest appreciation to Sakha agricultural research station, Kafrelsheikh Governate, for they kind and helpfulness during this study.

\section{References}

1. Contreras GA, Sordillo LM. Lipid mobilization and inflammatory responses during the transition period of dairy cows. Comp Immunol Microbiol Infect Dis. 2011;34(3):281-9.

2. Van Saun RJ. Indicators of dairy cow transition risks: Metabolic profiling revisited. Tierarztl Prax Ausg G Grosstiere Nutztiere. 2016;44(2):11826.

3. Drackley JK. Biology of dairy cows during the transition period: The final frontier? Journal of Dairy Science. 1999;82(11):2259-73.

4. Schröder UJ, Staufenbiel R. Invited review: Methods to determine body fat reserves in the dairy cow with special regard to ultrasonographic measurement of backfat thickness. Journal of Dairy Science. 2006;89(1):1-14.

5. Mulvany P. 6.5 Dairy cow condition scoring. BSAP Occasional Publication. 1981; 4:349-53.

6 . Roche JR, Friggens NC, Kay JK, Fisher MW, Stafford KJ, Berry DP. Invited review: Body condition score and its association with dairy cow productivity, health, and welfare. Journal of Dairy Science. 2009;92(12):5769-801.

7. Bell AW. Regulation of organic nutrient metabolism during transition from late pregnancy to early lactation. J Anim Sci. 1995;73(9):2804-19.

8. Duffield TF, Lissemore KD, McBride BW, Leslie KE. Impact of hyperketonemia in early lactation dairy cows on health and production. J Dairy Sci. 2009;92(2):571-80.

9. Edmonson A, Lean I, Weaver L, Farver T, Webster G. A body condition scoring chart for Holstein dairy cows. Journal of Dairy Science. 1989;72(1):68-78.

10. NRC. Nutrient Requirements of Dairy Cattle: Seventh Revised Edition. The National Academies. Press, Washington, DC. 2001;92(12):5770-95.

11. Ohkawa H, Ohishi N, Yagi K. Assay for lipid peroxides in animal tissues by thiobarbituric acid reaction. Analytical Biochemistry. 1979;95(2):351-8.

12. Snedecor GW, Cochran WG. Statistical methods, 8thEdn. Ames: Iowa State Univ Press Iowa. 1989; 6(4):329-35.

13. Duncan DB. Multiple range and multiple F tests. Biometrics. 1955;11(1):1-42.
14. Treacher R, Reid I, Roberts C. Effect of body condition at calving on the health and performance of dairy cows. Animal Science. 1986;43(1):1-6.

15. Pires J, Delavaud C, Faulconnier Y, Pomies D, Chilliard Y. Effects of body condition score at calving on indicators of fat and protein mobilization of periparturient Holstein-Friesian cows. Journal of Dairy Science. 2013;96(10):6423-39.

16. Jamali Emam Gheise N, Riasi A, Zare Shahneh A, Celi P, Ghoreishi SM. Effect of pre-calving body condition score and previous lactation on BCS change, blood metabolites, oxidative stress and milk production in Holstein dairy cows. Italian Journal of Animal Science. 2017;16(3):474-83.

17. Weber C, Hametner C, Tuchscherer A, Losand B, Kanitz E, Otten W, et al. Variation in fat mobilization during early lactation differently affects feed intake, body condition, and lipid and glucose metabolism in high-yielding dairy cows. Journal of Dairy Science. 2013;96(1):165-80.

18. Bauman D. Regulation of nutrient partitioning during lactation: homeostasis and homeorhesis revisited. Ruminant physiology: digestion, metabolism, growth and reproduction. 2000; 1:311-28.

19. García A, Cardoso FC, Campos R, Thedy DX, González FH. Metabolic evaluation of dairy cows submitted to three different strategies to decrease the effects of negative energy balance in early postpartum. Pesquisa Veterinária Brasileira. 2011;31:11-7.

20. Mouffok C-E, Madani T, Semara L, Ayache $\mathrm{N}$, Rahal A. Correlation between body condition score, blood biochemical metabolites, milk yield and quality in Algerian Montbéliarde cattle. Pakistan Vet J. 2013;33(33):191-4.

21. Kaewlamun W, Okouyi M, Humblot P, Remy D, Techakumphu M, Duvaux-Ponter C, et al. Effects of a dietary supplement of $\beta$-carotene given during the dry period on milk production and circulating hormones and metabolites in dairy cows. Revue Méd Vét. 2012;163(5):235-41.

22. Cheng X, Zhe W, Li Y-F, Niu S-L, Chuang $\mathrm{X}$, Zhang $\mathrm{C}$, et al. Effect of hypoglycemia on performances, metabolites, and hormones in periparturient dairy cows. Agricultural Sciences in China. 2007;6(4):505-12.

23. González F, Muiño R, Pereira V, Campos R, Castellote J. Blood indicators of lipomobilization and hepatic function in high yielding dairy cows during early lactation. Ciência Animal Brasileira. 2009;10(Supplement 1):64-9.

24. Bernard L, Leroux C, Chilliard Y. Expression and nutritional regulation of lipogenic genes in the 
ruminant lactating mammary gland. Bioactive components of milk: Springer; 2008. p. 67-108.

25. Remppis S, Steingass H, Gruber L, Schenkel H. Effects of energy intake on performance, mobilization and retention of body tissue, and metabolic parameters in dairy cows with special regard to effects of pre-partum nutrition on lactation-a review. Asian-Australasian Journal of Animal Sciences. 2011;24(4):540-72.

26. Soca P, Carriquiry M, Claramunt M, Gestido $\mathrm{V}$, Meikle A. Metabolic and endocrine profiles of primiparous beef cows grazing native grassland. 1. Relationships between body condition score at calving and metabolic profiles during the transition period. Animal Production Science. 2014;54(7):85661.

27. Civelek T, Aydin I, Cingi CC, Yilmaz O, Kabu M. Serum non-esterified fatty acids and betahydroxybutyrate in dairy cows with retained placenta. Pakistan Veterinary Journal. 2011;31(4): 341-4.

28. Ling K, Jaakson H, Samarütel J, Leesmäe A. Metabolic status and body condition score of Estonian Holstein cows and their relation to some fertility parameters. Veterinarija ir zootechnika. 2003;26:24.

29. Turk R, Podpečan O, Mrkun J, Kosec M, Flegar-Meštrić Z, Perkov S, et al. Lipid mobilisation and oxidative stress as metabolic adaptation processes in dairy heifers during transition period. Animal reproduction science. 2013;141(3-4):109-15.

30. Celi P, Gabai G. Oxidant/antioxidant balance in animal nutrition and health: the role of protein oxidation. Frontiers in Veterinary Science. 2015;2:48.

31. Gymnich S, Knura-Deszczka S, Wimmers K,
Bidlingmaier M, Schellander K, Petersen B. Haptoglobin as an indicator for animal welfare: Effects of different hygienic conditions and transport stress on haptoglobin plasma concentration. Acta Veterinaria Scandinavica. 2003;44(1):P33.

32. Vargová M, Hromada R, Veszelits Laktičová K, Pošiváková T, Benculák J, Kováč G. Correlations between acute phase proteins and the body condition score. Acta Veterinaria Brno. 2018;86(4):339-44.

33. Montagner P, Tavares Krause AR, Schwegler E, Menoncin Weschenfelder M, Stein Maffi A, Gularte Xavier E, et al. Relationship between pre-partum body condition score changes, acute phase proteins and energy metabolism markers during the peripartum period in dairy cows. Italian Journal of Animal Science. 2017;16(2):329-36.

34. Colakoglu HE, Yazlik MO, Kaya U, Colakoglu EC, Kurt S, Oz B, et al. MDA and GSHPx activity in transition dairy cows under seasonal variations and their relationship with reproductive performance. Journal of Veterinary Research. 2017;61(4):497-502.

35. Castillo C, Hernandez J, Bravo A, LopezAlonso M, Pereira V, Benedito J. Oxidative status during late pregnancy and early lactation in dairy cows. The Veterinary Journal. 2005;169(2):286-92.

36. Abd Ellah MR. Oxidant and antioxidants during the transition period in dairy cows. Journal of Advanced Veterinary Research. 2016;6(4):130-3.

37. Bernabucci U, Ronchi B, Lacetera N, Nardone A. Influence of body condition score on relationships between metabolic status and oxidative stress in periparturient dairy cows. Journal of Dairy Science. 2005;88(6):2017-26. 